\title{
Ratooning ability and its relationship among yield, quality and lesser sugarcane borer (Chilo
} agamemnon Bels.) in of sugarcane germplasm

\author{
Fahmy, A.M. ${ }^{1}$, Wafaa E. Grad ${ }^{2}$, and E.M. Mehareb *2 \\ ${ }^{1}$ Plant Protection Dept., Fac. Agri. and Natural Resources, Aswan University, Egypt. \\ ${ }^{2}$ Breeding \& Genetic Dept., Sugar Crops Research Inst., ARC, Giza, Egypt
}

\begin{abstract}
This study was conducted at El-Mattana Agricultural Research Station, Luxor Governorate, Egypt (latitude of $25.17^{\circ} \mathrm{N}$ and longitude of $32.33^{\circ} \mathrm{E}$ ) on three sugar crop cycles 2017/18 (plant cane crop), 2018/19 (the first ratoon) and 2019/20 (the second ratoon) to screen sugarcane genotypes for yield, quality and borer resistance, also estimates the relationship among agronomical and pathological traits based on principal components biplot analysis. Results revealed that significant differences among sugarcane genotypes in susceptibility to the lesser sugarcane borer, Chilo agamemnon infestation measured as bored stalk\%, bored joints \%, girdled stalks\%, mean no. holes/joint, mean no. holes/bored joint and mean no. holes/stalk in the three studied seasons. In plant cane and first ratoon seasons the genotype L 62-96 exhibited the highest bored stalk \%. While, in the second ratoon, the genotype G.T.54-9 was recorded the highest bored stalk \%. Three genotypes (F. 150, M 5735 and G. 2008-20) were the most tolerant in plant cane season recording the lowest bored stalk\%. While, in the $1^{\text {st }}$ ratoon season, 88/5-27 and SP72-5181 genotypes were recording lowest bored stalk\%. Meanwhile, in the $2^{\text {nd }}$ ratoon season, SP 81-3250, F. 150, F 161 and G. 2007-61 genotypes were recording lowest bored stalk\% respectively.
\end{abstract}

\section{Keywords:}

\section{Introduction}

Sugarcane belonging to family Poaceae is a significant currency crop that is infected from various borers from first step in planting to final step in collecting yield (Kumar et al., 2019). This prompts exceptional decrease in generally sugar cane yield and sugar recovery. Insect pests like Lepidopterous borers are one of the significant causes in decreasing the

\footnotetext{
*Corresponding author: Eid M. Mehareb

Email: elmoharb@yahoo.com

Received: March 27, 2021; Accepted: May 8, 2021,

Published online: May 10, 2021.

(C) Published by South Valley University.
}

This is an open access article licensed under @()이이 millable canes and overall cane yield (Sharma, 2011). Sugarcane crop is affected by borer which caused great losses in yield and sugar. Borer infestation causes reduction in cane weight due to internodes damage, in addition larval tunnel in the cane cause stalk breakage and lodging. Moreover, the larval entrance and moth holes offer entry points for red rot. So, the primary responsibility of plant breeders and pathologists in regard to host plant resistance is to produce an economically viable variety that will benefit both the producer and the consumer (Mehareb et al., 2018). The primary goal of most sugarcane breeding 
programs is to develop cultivars with improved cane and sugar yields. Sugarcane is a clonally propagated crop and in Egypt it is typically harvested for plant cane and a number of ratoon crops. Unfortunately, yields of younger crops fail to adequately predict subsequent ratoon yields (Ramdoyal et al., 1986). First ratoon yields commonly equal plant cane yields but yield decline is often severe in second ratoon crops. Hence, selection for high second ratoon yielding ability requires testing through this crop. Because second ratoon yield potential is an essential cultivar characteristic, a study investigating crop effects should include the second ratoon to be meaningful.

Ratoon ability (RA) in sugarcane is the ability to maintain yields as the number of ratoon crops increase. It is desirable character because it improves the economics of sugar production. Ratooning ability is an important integral component of sugarcane production worldwide as it not only reduces cost of cultivation but also dispenses with the requirement of seed material and some cultural practices like preparation and preparatory irrigation. In addition, it also results in early maturity of canes at least by one month and thus adds to the effective crushing period (Saxena et al., 2010). The plant characters of sugarcane associated with ratoon ability were studied for possible use as selection criteria in breeding Zhou and Shoko (2012). The major cane growing countries normally take two or more ratoons (Bashir et al., 2013). Ratoon crop yields usually decrease with age and, hence, limit the economic production of sugarcane (Masri and Amein, 2015). Nowadays, Selection in the ratoon crops was most effective for genetic gain (Gravois et al., 2016).
Rare searches concerning the genetic characters for the resistance of sugarcane to borers, like spotted borer Chilo sacchariphagus (Lepidoptera: Pyralidae), which have been reported by (Tomaz et al., 2019). Fahmy et al. (2017) showed that the sugarcane varieties differed significantly in their susceptibility to $C$. agamemnon infestation Mehareb et al., (2018) tested 47 varieties of sugarcane in Egypt against $C$. agamemnon and reported that, out of 47 varieties only 3 were found resistant and the remaining were moderately resistant. What's more, there is a requirement for more searches concerning selection for borer resistance, also, to yield qualities, since select just for borer resistance may bring about genotypes with ominous qualities and lower sugar yield (Tomaz et al., 2020). The objectives of this study were to estimate the ratooning ability for studied sugarcane genotypes, screening sugarcane genotypes for yield, quality and borer resistance, also estimates the relationship among agronomical and pathological traits based on principal components biplot analysis.

\section{Materials and Methods}

\subsection{Plant material and experimental conditions}

A complete randomized experiment was done in four replication; plot size was $42 \mathrm{~m}^{2}$ consist of six rows, seven $\mathrm{m}$ in length and one meter in width. A filed experiments was carried out at El-Mattana Agricultural Research Station, Luxor Governorate, Egypt (latitude of $25.17^{\circ}$ $\mathrm{N}$ and longitude of $\left.32.33^{\circ} \mathrm{E}\right)$ for three successive seasons 2017/18 (Plant cane crop), 2018/19 (The first ratoon) and 2019/20 (The second ratoon) to evaluate some sugarcane 
genotypes (Table 1) under Egyptian conditions.

Table 1. Geographic origins of tested cane materials

\begin{tabular}{ccclll}
\hline NO & Genotypes & Origin & NO & Genotypes & Origin \\
\hline 1 & G.2003-47 & Egypt, Giza & 9 & L 62-96 & USA (Louisiana) \\
2 & EH 88/5-27 & Howmdia,Egypt, & 10 & G. 2008-20 & Egypt, Giza \\
3 & F. 150 & Taiwan & 11 & G. 2007-61 & Egypt, Giza \\
4 & M 57-35 & Mauritius & 12 & SP 81-3250 & Brazil, Sao Paulo \\
5 & F 161 & Taiwan & 13 & CO 182 & India, Coimbatore \\
6 & SP72-5181 & Brazil,Sao Paulo & 14 & G.2006-36 & Egypt, Giza \\
7 & G. 2008-64 & Egypt, Giza & 15 & G.T.54-9 & Egypt, Giza \\
8 & G. 2003-49 & Egypt, Giza & & & \\
\hline
\end{tabular}

\subsection{The recorded Data}

Data recorded for the three sugarcane crop (sugar plant cane, $1^{\text {st }}$ ratoon and its $2^{\text {nd }}$ ratoon), twenty cane stalks were collected at random to determine the following traits.

\subsection{Susceptibility of sugarcane genotypes to infestation with the lesser sugarcane borer, Chilo agamemnon Bels.}

Samples of 20 stalks were taken randomly from the middle rows of each plot during harvest time for the studied sugarcane genotypes. Cane stalks were stripped, cleaned and examined for various noticeable sign of infestation with $C$. agamemnon before juicing. The infestation levels of sugar plant cane, $1^{\text {st }}$ ratoon and its $2^{\text {nd }}$ ratoon were measured using the following formula, according to Mendes et al. (1980):

1- Percentage of bored stalks (infestation incidence $\%)$.

Infestation incidence $\%=($ No. of bored stalks / No. of examined stalks) $\times 100$.

2- Percentage of bored joints (infestation intensity $\%)$.

Infestation intensity $\%=($ No. of bored joints / No. of examined joints) $\times 100$.

3- Percentage of girdled stalks $=$ No. of girdled stalks / No. of examined stalks $\times 100$.
4- Mean of holes $/$ joint $=$ No. of holes $/$ No. of examined joints.

5- Mean of holes / bored joint $=$ No. of holes $/$ No. of examined bored joints.

6- Mean of holes $/$ stalk $=$ No. of holes $/$ No. of examined stalks.

\subsection{Chemical analysis}

Samples of sugarcane juice produced (after one hour from harvesting) from these stalks was conducted. One-liter juice of them was taken in glass cylinder for calculating the characters to determine the following parameters:

1- Brix percentage was determined using "Brix Hydrometer" standardized at $20^{\circ} \mathrm{C}$.

2- Sucrose percentage was determined using "Sacharemeter" according to A.O.A.C. (1995).

3- Purity percentage was calculated according to the following equation of Singh and

Singh (1998) as Purity percentage $=$ sucrose percentage $\mathrm{x} 100$ / brix percentage

4- Sugar recovery percentage: was calculated according to the formula described by Yadav and Sharma 1980 as Sugar recovery (SR)

$\mathrm{SR} \%=[$ sucrose $\%-0.4$ (brix $\%$ - sucrose

$\%) \times 0.73]$.

\subsection{Productivity traits}


1- Cane yield (ton/ fed.) was determined from the four guarded rows of each plot converted into a value per fed.

2- Sugar yield (ton/ fed.) was estimated according to following equation:

Sugar yield (ton/ fed.) = cane yield (tons/fed.) $\mathrm{x}$ sugar recovery $\%$.

\subsection{Statistical analysis}

Data was submitted to analysis of variance by the F-test $(\mathrm{p}<0.05)$. Means were compared by the Tukey's test $(p<0.05)$.

\subsection{Principal Component Analysis (PCA)}

PCA method described by Harman (1976) was followed in the extraction of the components. PCA was performed by Minitab 14 software.

\section{Results and Discussion}

\subsection{Performance crop cycles for some sugarcane germplasm}

Data offered in Table 2 showed significant differences among studied genotypes with respect to brix \%, purity $\%$, sugar recovery $\%$, cane and the sugar yield in plant cane (PC), first ratoon (FR), and second ratoon (SR). The genotype of crop cycle interaction was significantly affected thee valuated characteristics, which revealed that performance of the genotypes vary among the crop cycles. It has been stated that genotype of crop interaction was important for sugarcane yield and its component characters (Mahmoud et al., 2012 and Khan et al., 2013). Brix\% varied from $20.9 \%$ for the commercial variety G.T.54-9 to $18.26 \%$ for the genotype EH 88/527 in plant cane. By contrast, in first ratoon crop, the genotype SP 72-5181 gave significantly better brix $\%$ as compared to the check cultivar G.T.54-9. Additionally, the genotype L 62-96 gave significantly better brix \% as compared to the check cultivar G.T.54-9 in first ratoon and second ratoon. Furthermore, Brix\% of most of the genotypes fluctuated among crops; these results are in agreement with those mentioned by Mehareb, et al., 2017; Mehareb and Abazied 2017, who found that the tested varieties significantly differed in brix\%. Purity\% of seven genotypes; G. 2003-47, M 57-35, G. 2008-64, G. 2003-49, L 62-96, SP 81-3250 and G. 2006-36 gave significantly higher purity $\%$ as compared to the check cultivar G.T.54-9 in plant cane. On the other hand, Purity\% of six genotypes; G. 2003-47, EH 88/5-27, F.150, M 57-35, SP 725181 and G. 2003-49 gave significantly higher purity $\%$ as compared to the check cultivar in first ratoon. But Purity\% of most genotypes recorded significantly higher of purity $\%$ value as compared GT.54-9 in second ratoon. These results are harmony with those found by Khan et al., (2013); Gadallah and Mehareb (2020) who found that the studied varieties significantly varied in purity\%. Sugar recovery gave significant differences among evaluated genotypes over crops.

Generally, the crop cycle (plant cane, first ratoon and second ratoon) had no effect on juice quality traits (brix\%, sucrose $\%$, purity $\%$ and sugar recovery\%). Mehareb and Galal (2017) reported that genotype in consecutive crop generations tend to mature earlier than previous crops, however final sucrose $\%$ and its components, brix concentration, sucrose content, purity $\%$ and sugar recovery $\%$ are usually not affected by crop cycle. These results are harmony with those found by Abo elenen et al. (2018) who reported that generations had no effect on juice quality traits. 
Table 2. Mean performance of studied sugarcane genotypes for Brix \%, sucrose \%, purity\%, sugar recovery\% and sugar yield (t/fed) in plant cane (PC), first ratoon (FR) and second ratoon (SR)

\begin{tabular}{|c|c|c|c|c|c|c|c|c|c|c|c|c|c|c|c|c|c|c|}
\hline \multirow{2}{*}{$\begin{array}{c}\text { Parameter } \\
\text { Genotype }\end{array}$} & \multicolumn{3}{|c|}{ Sucrose $\%$} & \multicolumn{3}{|c|}{ Brix \% } & \multicolumn{3}{|c|}{ Purity $\%$} & \multicolumn{3}{|c|}{ sugar recovery } & \multicolumn{3}{|c|}{ Cane yield } & \multicolumn{3}{|c|}{ Sugar yield } \\
\hline & $\mathrm{PC}$ & FR & SR & $\mathrm{PC}$ & FR & SR & $\mathrm{PC}$ & FR & SR & $\mathrm{PC}$ & FR & SR & PC & FR & SR & $\mathrm{PC}$ & FR & SR \\
\hline $\begin{array}{c}\text { G.2003- } \\
47\end{array}$ & $15.98^{\mathrm{ef}}$ & $18.67^{\mathrm{d}}$ & $18.48^{\mathrm{c}}$ & $19.65^{\mathrm{cd}}$ & $21.38^{\mathrm{a}}$ & $20^{1}$ & $81.32^{\mathrm{e}}$ & $87.33^{\mathrm{c}}$ & $92.39^{\mathrm{b}}$ & $10.59^{\text {efg }}$ & $12.84^{\mathrm{e}}$ & $13.04^{\mathrm{b}}$ & $53.7^{\mathrm{e}}$ & $59.3^{\text {cd }}$ & $60.3^{\mathrm{de}}$ & $5.6^{\mathrm{cd}}$ & $7.9^{\mathrm{abcd}}$ & $7.6^{\mathrm{bc}}$ \\
\hline $\begin{array}{c}\text { EH 88/5- } \\
27\end{array}$ & $13.50^{\mathrm{i}}$ & $19.23^{\mathrm{a}}$ & $15.67^{\mathrm{n}}$ & $18.26^{\mathrm{g}}$ & $20.39^{c d}$ & $20^{\mathrm{k}}$ & $73.92^{\mathrm{i}}$ & $94.29^{\mathrm{a}}$ & $78.35^{\mathrm{n}}$ & $8.46^{\mathrm{k}}$ & $13.69^{\mathrm{a}}$ & $10.17^{\mathrm{n}}$ & $58.5^{\mathrm{bc}}$ & $63.6^{\mathrm{b}}$ & $65.9^{\mathrm{abc}}$ & $4.9^{\mathrm{ef}}$ & $8.7^{\mathrm{a}}$ & $6.7^{\mathrm{efg}}$ \\
\hline F. 150 & $14.61^{\mathrm{gh}}$ & $18.68^{\mathrm{d}}$ & $19.22^{\mathrm{a}}$ & $19.45^{\mathrm{de}}$ & $21.24^{\mathrm{ab}}$ & $20.2^{\mathrm{g}}$ & $75.12^{\mathrm{h}}$ & $87.95^{\mathrm{bc}}$ & $95.13^{\mathrm{a}}$ & $9.25^{\mathrm{i}}$ & $12.89^{\mathrm{d}}$ & $13.74^{\mathrm{a}}$ & $51.0^{\mathrm{fg}}$ & $55.5^{\mathrm{ef}}$ & $58.5^{\mathrm{e}}$ & $4.7^{\mathrm{f}}$ & $7.1^{\text {abcde }}$ & $8.0^{\mathrm{b}}$ \\
\hline M 57-35 & $15.78^{\mathrm{f}}$ & $18.15^{\mathrm{e}}$ & $17.00^{\mathrm{j}}$ & $19.35^{\text {def }}$ & $20.39^{\mathrm{cd}}$ & $20^{\mathrm{j}}$ & $81.57^{\mathrm{e}}$ & $89^{\mathrm{b}}$ & $85.01^{\mathrm{j}}$ & $10.48^{\mathrm{fg}}$ & $12.59^{\mathrm{f}}$ & $11.54^{\mathrm{j}}$ & $45.5^{\mathrm{h}}$ & $51.2^{\mathrm{g}}$ & $52.2^{\mathrm{f}}$ & $4.8^{\mathrm{f}}$ & $6.4^{\text {cdef }}$ & $6.0^{\mathrm{h}}$ \\
\hline F 161 & $14.60^{\mathrm{gh}}$ & $16.22^{1}$ & $17.83^{\mathrm{h}}$ & $18.75^{\mathrm{fg}}$ & $20.84^{b c}$ & $19.5^{\mathrm{n}}$ & $77.89^{\mathrm{g}}$ & $77.83^{\mathrm{g}}$ & $91.43 \mathrm{c}$ & $9.45^{\mathrm{i}}$ & $10.50^{\mathrm{m}}$ & $12.53^{\mathrm{f}}$ & $54.0^{\mathrm{de}}$ & $59.4^{\mathrm{cd}}$ & $58.2^{\mathrm{e}}$ & $5.1^{\mathrm{def}}$ & $6.2^{\mathrm{ef}}$ & $7.2^{\mathrm{cd}}$ \\
\hline $\begin{array}{l}\text { SP72- } \\
5181\end{array}$ & $15.96^{\mathrm{ef}}$ & $19.16^{\mathrm{b}}$ & $17.82^{\mathrm{i}}$ & $20.46^{\mathrm{ab}}$ & $21.68^{\mathrm{a}}$ & $20^{\mathrm{i}}$ & $78.02^{\mathrm{g}}$ & $88.37^{b c}$ & $89.09^{\mathrm{f}}$ & $10.34^{\mathrm{g}}$ & $13.25^{\mathrm{b}}$ & $12.37^{\mathrm{h}}$ & $56.4^{\mathrm{cd}}$ & $60.4^{\mathrm{bcd}}$ & $59.4^{\mathrm{de}}$ & $5.8^{\mathrm{bc}}$ & $8.0^{\mathrm{abc}}$ & $7.3^{\mathrm{cd}}$ \\
\hline $\begin{array}{c}\text { G. } 2008- \\
64\end{array}$ & $15.87^{\mathrm{f}}$ & $16.83^{\mathrm{j}}$ & $18.02^{\mathrm{f}}$ & $18.76^{\mathrm{fg}}$ & $21.24^{\mathrm{ab}}$ & $20.2^{\mathrm{f}}$ & $84.64^{\mathrm{d}}$ & $79.24^{\mathrm{fg}}$ & $89.19^{e}$ & $10.74^{\mathrm{ef}}$ & $11.01^{\mathrm{k}}$ & $12.51^{\mathrm{g}}$ & $64.2^{\mathrm{a}}$ & $68.9^{\mathrm{a}}$ & $67.8^{\mathrm{ab}}$ & $6.8^{\mathrm{a}}$ & $7.5^{\text {abcde }}$ & $8.4^{\mathrm{a}}$ \\
\hline $\begin{array}{c}\text { G. } 2003- \\
49\end{array}$ & $17.27^{\mathrm{bc}}$ & $18.90^{\mathrm{c}}$ & $17.89^{\mathrm{g}}$ & $20.16^{\mathrm{bc}}$ & $21.44^{\mathrm{a}}$ & $20.3^{\mathrm{e}}$ & $85.65^{\mathrm{c}}$ & $88.17^{\mathrm{bc}}$ & $88.13^{\mathrm{g}}$ & $11.76^{\mathrm{c}}$ & $13.06^{\mathrm{c}}$ & $12.36^{\mathrm{i}}$ & $45.8^{\mathrm{h}}$ & $50.9^{\mathrm{g}}$ & $50.8^{\mathrm{f}}$ & $5.3^{\text {cde }}$ & $6.6^{\mathrm{cde}}$ & $6.2^{\mathrm{gh}}$ \\
\hline L 62-96 & $16.90^{\mathrm{cd}}$ & $17.22^{\mathrm{g}}$ & $18.40^{\mathrm{d}}$ & $20.67^{a b}$ & $21.63^{\mathrm{a}}$ & $21.2^{\mathrm{a}}$ & $81.73^{\mathrm{e}}$ & $79.61^{\mathrm{f}}$ & $86.78^{\mathrm{i}}$ & $11.23^{\mathrm{d}}$ & $11.28^{\mathrm{j}}$ & $12.61^{\mathrm{d}}$ & $48.8^{\mathrm{g}}$ & $53.2 \mathrm{f}^{\mathrm{g}}$ & $52.7^{\mathrm{f}}$ & $5.4^{\text {cde }}$ & $6.0^{\mathrm{ef}}$ & $6.6^{\mathrm{fg}}$ \\
\hline $\begin{array}{l}\text { G. } 2008- \\
20\end{array}$ & $16.29^{\mathrm{def}}$ & $18.03^{\mathrm{f}}$ & $16.32^{1}$ & $20.46^{\mathrm{ab}}$ & $21.63^{\mathrm{a}}$ & $20.5^{\mathrm{d}}$ & $79.61^{\mathrm{f}}$ & $83.36^{\mathrm{de}}$ & $79.6^{\mathrm{m}}$ & $10.67^{\mathrm{ef}}$ & $12.11^{\mathrm{h}}$ & $10.69^{\mathrm{m}}$ & $63.9^{\mathrm{a}}$ & $68.1^{\mathrm{a}}$ & $69.2^{\mathrm{a}}$ & $6.8^{\mathrm{a}}$ & $8.2^{\mathrm{ab}}$ & $7.4^{\mathrm{cd}}$ \\
\hline $\begin{array}{c}\text { G. } 2007- \\
61\end{array}$ & $13.98^{\mathrm{hi}}$ & $14.78^{\mathrm{m}}$ & $18.57^{\mathrm{b}}$ & $18.86^{\text {efg }}$ & $20.74^{c}$ & $20.5^{\mathrm{c}}$ & $74.15^{\mathrm{i}}$ & $71.28^{\mathrm{h}}$ & $90.58^{d}$ & $8.78^{\mathrm{j}}$ & $9.05^{\mathrm{n}}$ & $12.99^{\mathrm{c}}$ & $62.6^{\mathrm{a}}$ & $68.9^{\mathrm{a}}$ & $68.3^{\mathrm{ab}}$ & $5.5^{\mathrm{cde}}$ & $6.2^{\mathrm{ef}}$ & $8.8^{\mathrm{a}}$ \\
\hline $\begin{array}{l}\text { SP 81- } \\
3250\end{array}$ & $17.98^{\mathrm{a}}$ & $14.56^{\mathrm{n}}$ & $18.36^{\mathrm{e}}$ & $19.76^{\mathrm{cd}}$ & $21.34^{\mathrm{a}}$ & $21.1^{\mathrm{b}}$ & $90.98^{a}$ & $68.21^{\mathrm{i}}$ & $87.01^{\mathrm{h}}$ & $12.6^{\mathrm{a}}$ & $8.64^{\circ}$ & $12.60^{\mathrm{e}}$ & $52.1^{\mathrm{ef}}$ & $57.3^{\mathrm{de}}$ & $58.7^{\mathrm{de}}$ & $6.6^{\mathrm{a}}$ & $4.9^{\mathrm{f}}$ & $7.4^{\mathrm{cd}}$ \\
\hline CO 182 & $15.06^{\mathrm{g}}$ & $16.50^{\mathrm{k}}$ & $14.22^{\circ}$ & $18.95^{\mathrm{ef}}$ & $20.84^{\mathrm{bc}}$ & $19^{\circ}$ & $79.49^{f}$ & $79.17^{\mathrm{fg}}$ & $74.82^{\circ}$ & $9.86^{\mathrm{h}}$ & $10.77^{1}$ & $8.98^{\circ}$ & $53.4^{\mathrm{ef}}$ & $58.7^{\text {cde }}$ & $57.3^{\mathrm{e}}$ & $5.3^{\text {cdef }}$ & $6.3^{\mathrm{def}}$ & $5.2^{\mathrm{i}}$ \\
\hline $\begin{array}{c}\text { G.2006- } \\
36\end{array}$ & $17.79^{\mathrm{ab}}$ & $17.10^{\mathrm{h}}$ & $16.17^{\mathrm{m}}$ & $20.46^{\mathrm{ab}}$ & $20.74^{c}$ & $19.6^{\mathrm{m}}$ & $86.97^{\mathrm{b}}$ & $82.47^{\mathrm{e}}$ & $82.44^{1}$ & $12.21^{\mathrm{b}}$ & $11.42^{\mathrm{i}}$ & $10.80^{1}$ & $56.3^{\mathrm{cd}}$ & $60.9^{b c}$ & $62.4^{\mathrm{cd}}$ & $6.9^{\mathrm{a}}$ & $6.9^{\text {bcde }}$ & $6.7^{\mathrm{ef}}$ \\
\hline G.T.54-9 & $16.60^{\text {cde }}$ & $16.98^{\mathrm{i}}$ & $16.50^{\mathrm{n}}$ & $20.9^{\mathrm{a}}$ & $20.07^{\mathrm{d}}$ & $20^{\mathrm{h}}$ & $79.2^{\mathrm{f}}$ & $84.62^{\mathrm{d}}$ & $82.49^{\mathrm{k}}$ & $10.86^{\mathrm{e}}$ & $11.49^{\mathrm{h}}$ & $11.02^{\mathrm{k}}$ & $59.0^{\mathrm{b}}$ & $63.3^{\mathrm{b}}$ & $64.8^{\mathrm{bc}}$ & $6.4^{\mathrm{ab}}$ & $7.2^{\mathrm{bcde}}$ & $7.1^{\mathrm{de}}$ \\
\hline
\end{tabular}

*Means followed by the same letter do not differ by the Tukey's test $(\mathrm{p}<0.05)$. 
Cane yield of three genotypes, G. 2008-64, G. 2008-20 and G. 2007-61 gave significantly higher cane yield as compared to with the check cultivar G.T.54-9, which were $108.73 \%, 108.93 \%$ For G. 2008-64, $108.37 \%, 107.65 \%$ for G. 2008-64 and $106.17 \%, 108.91 \%$ for G. $2007-61$ of the mean of the check cultivar G.T.54-9 in plant cane, and the first ratoon, respectively. But in the second ratoon, cane yield of one genotype, G. 2008-20 gave significantly higher cane yield as compared to with the check cultivar, which was $106.86 \%$ of the mean of the cultivar. Cane yield of six genotypes; F 161, SP 72-5181 and G. 2008-64 fluctuated for cane yield with older crop cycles. While cane yield of nine genotypes registered an increasing trend with older crop cycles

Sugar yield of four genotypes, G 2008-64, G 2008-20, SP 81-3250 and G 2006-36 gave higher sugar yield as compared to GT.54-9, which were $107.55 \%, 106.45 \%, \quad 102.52$ and $107.27 \%$, respectively, of the mean of the GT54-9 in plant cane. By contract, in the second ratoon, sugar yield of four genotypes, G 2003-47, F.150, G 2008-64 and G 2007-61 gave significantly higher cane yield as compared to the check cultivar , which were $106.52 \%$ of $112.55 \%, 118.90 \%$ the $124.39 \%$ of the mean of the cultivar.
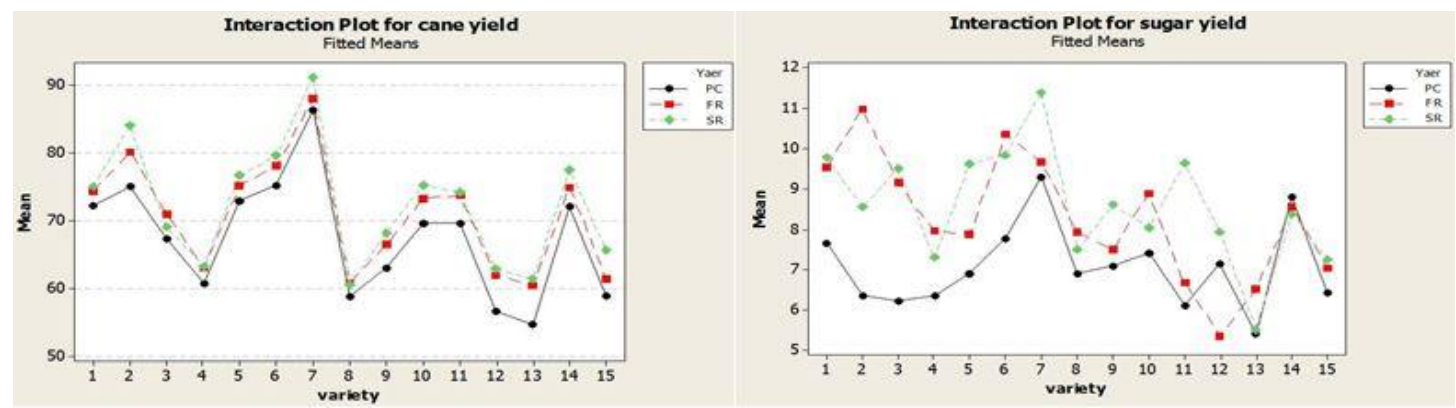

Figure 1. Cane and sugar yield traits across crop cycles.

\subsection{Ratooning ability}

All studied genotypes along with the check variety showed better ratooning ability for brix \%, sucrose $\%$, purity $\%$, sugar recovery $\%$, cane yield and sugar yield presented in figure 2 (a-f). Brix percentage, for all genotypes showed an increase in second ratoon as compared to the plant cane except two genotypes viz., G. 2006-36 and commercial variety G.T. 54-9; the highest RA value $(110.6 \%$ and $129.26 \%$ ) for brix and sucrose percentage was recorded by the genotype EH 88/5-27, fig.2 (a-b). All genotypes showed increase in sucrose $\%$ for the consecutive crop generations except two genotypes; SP 81-3250 and G. 2006-36 fig.2 (b). By contrast, the genotype F.150 recorded highest value of $121.86 \%$ and $143.91 \%$ for purity\% and sugar recovery\%, respectively fig.2 (c-d). Nine genotypes; G. 2003-47 (111.54), EH88/5-27 (110.75), F.150 (111.66), M 57-35(113.43), F 161 (108.89), G. 2003-49 (110.91\%), G. 2007-6 (109.55\% ), SP 81-3250 (111.34) and G. 2006-36 $(109.55 \%)$ recorded good ratooner for cane yield fig.2 (e)as compared to the check variety G.T.54- 9 (108.50\%). The genotype; F.150 give high value for sugar yield as compared to with the check variety G.T.54-9 (112.41\%), recording 49.1\% higher than that given by G.T.54-9 fig.2 (f). These results are in agreement with Zhao et al. (2020) who reported that the cane and sugar yield of some genotypes increased with consecutive crop cycles 

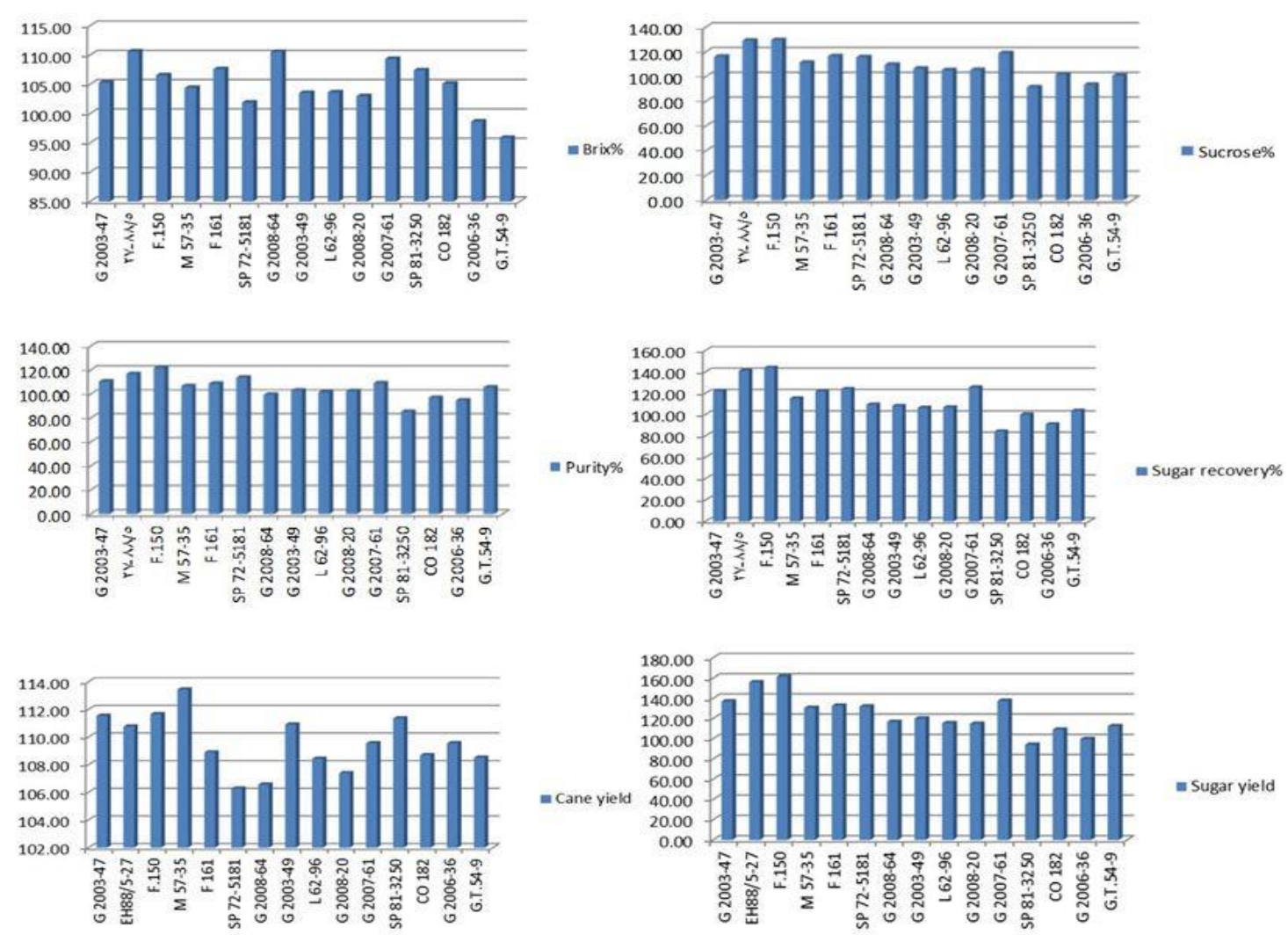

Fig. 2 (a-f). Ratooning ability percentage for (a) brix\%, (b) sucrose\%, (c) purity\%, (d) sugar recovery \% (e) cane yield and (f) sugar yield.

\subsection{Susceptibility of sugarcane genotypes to infestation with the lesser sugarcane borer, $C$. agamemnon Bels.}

Susceptibility of fifteen sugarcane genotypes to infestation with $C$. agamemnon was determined under natural conditions in the three successive seasons 2017/18 (plant cane), 2018/19 (first ratoon) and 2019/20 (second ratoon). Various noticeable signs of infestation were taken into consideration as measures and exact figures for estimating the main damage of $C$. agamemnon. These measures will be discussed as follows for plant cane, first and second ratoon canes:

\subsubsection{Bored stalks percentage (infestation incidence \%)}

Data arranged in Table (3) and Figure (3) showed that, bored stalks percentage in both plants cane, $1^{\text {st }}$ ratoon and $2^{\text {nd }}$ ratoon seasons significantly differed among sugarcane genotypes. In plant cane the genotype L 62-96 exhibited the highest bored stalks\% recording (45\%). The genotype next in order in its sensitivity to C. agamemnon attack was G. 2008-64 (40.0\%). While, in the $1^{\text {st }}$ ratoon the genotype G. 2003-49 recorded the highest bored stalks\% (46.67\%). On the contrary, in the $2^{\text {nd }}$ ratoon the genotype G.T.54-9 (86.67\%). On the other hand, F. 150, M 57-35 and G. 2008-20 were the most tolerant genotypes in plant cane recording the lowest bored stalks\% (10\%) respectively. While, in the $1^{\text {st }}$ ratoon two genotypes (EH88/527and SP72-5181) recording the lowest bored stalks\% $(15 \%)$. Whereas, in the $2^{\text {nd }}$ ratoon season five genotypes (SP 81-3250, F. 150, F 161, G. 2008-64 and G. 2007-61) were recorded the lowest bored stalks\%. 
Table 3. Susceptibility of sugarcane genotypes to infestation with C. agamemnon (Bored stalks \%) during three successive seasons (PC), (FR) and (SR)

\begin{tabular}{|c|c|c|c|}
\hline \multirow{2}{*}{ Genotypes } & \multicolumn{3}{|c|}{ Bored stalks \% } \\
\hline & $2017 / 18$ (PC) & 2018/19 (FR) & $2019 / 20(\mathrm{SR})$ \\
\hline G.2003-47 & $20^{\mathrm{de}}$ & $20^{\text {ce }}$ & $36.67^{b c}$ \\
\hline EH 88/5-27 & $30^{\mathrm{bc}}$ & $15^{\mathrm{e}}$ & $10^{\text {ef }}$ \\
\hline F. 150 & $10^{\mathrm{e}}$ & 26.67 bcde & $6.67^{f}$ \\
\hline M 57-35 & $10^{\mathrm{e}}$ & $25^{\text {bcde }}$ & $26.67^{\mathrm{cd}}$ \\
\hline F 161 & $15^{\text {de }}$ & $23.33^{\text {cde }}$ & $6.67^{\mathrm{f}}$ \\
\hline SP72-5181 & $15^{\mathrm{de}}$ & $15^{\mathrm{e}}$ & $46.67^{b}$ \\
\hline G. $2008-64$ & $40^{\mathrm{ab}}$ & $28.33 \mathrm{bcd}$ & $6.67^{f}$ \\
\hline G. $2003-49$ & $20^{\text {cde }}$ & $46.67^{\mathrm{a}}$ & $30^{\mathrm{cd}}$ \\
\hline L 62-96 & $45^{\mathrm{a}}$ & $45^{\mathrm{a}}$ & $36.67 \mathrm{bc}$ \\
\hline G. $2008-20$ & $10^{\mathrm{e}}$ & $35 \mathrm{abc}$ & 10 ef \\
\hline G. $2007-61$ & $15^{\mathrm{de}}$ & $30 \mathrm{bcd}$ & $6.67^{\mathrm{f}}$ \\
\hline SP $81-3250$ & $25^{\mathrm{cd}}$ & $28.33^{\mathrm{bcd}}$ & $5^{\mathrm{f}}$ \\
\hline CO 182 & $30^{\mathrm{bc}}$ & $35^{a b c}$ & $20^{\mathrm{de}}$ \\
\hline G.2006-36 & $20^{\text {cde }}$ & $18.33^{\mathrm{de}}$ & $10^{\text {ef }}$ \\
\hline G.T. 54-9 & $18.33^{\text {cde }}$ & $36.67^{a b}$ & $86.67^{a}$ \\
\hline
\end{tabular}

*Means followed by the same letter do not differ by the Tukey's test $(\mathrm{p}<0.05)$; 


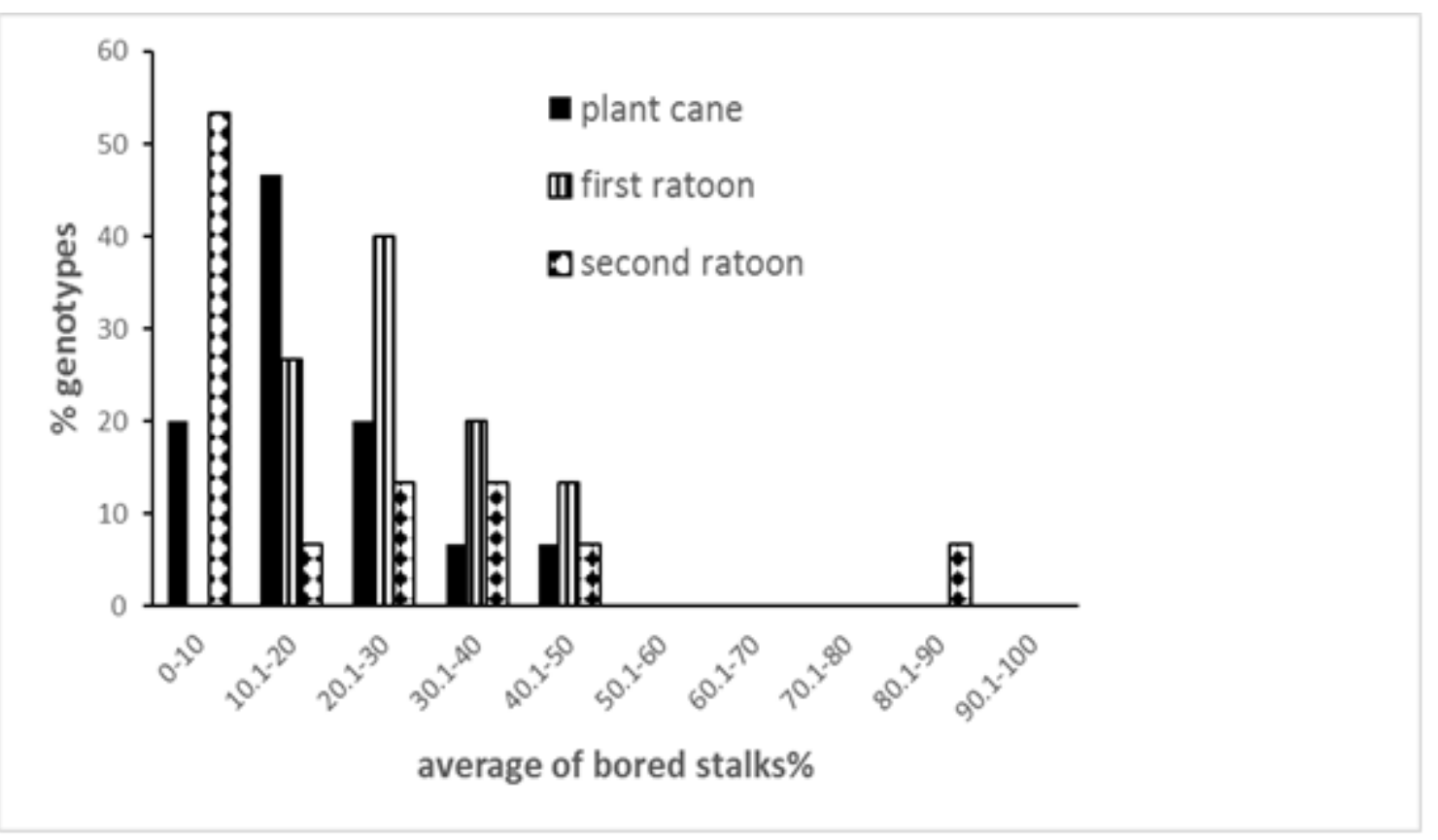

Figure 3. Percentage of sugarcane genotypes to infestation with C. agamemnon (bored stalks\%) during three successive seasons.

All sugarcane genotypes showed severe symptoms of infestation by C. agamemnon in plant cane, first ratoon and second ratoon seasons. There are numerous genotypes having similar percentage of bored stalks (10\%); F. 150, M 57-35, and G. 200820 in the plant cane and EH 88/5-27, G. 2008-20 and G.2006-36 in the second ratoon. In plant cane season, $20 \%$ of genotypes ranged from 0 to $10 \%$ bored stalks, $46.67 \%$ of genotypes ranged from 10.1 to $20 \%$ bored stalks, $20 \%$ of genotypes ranged from 20.1 to $30 \%$ bored stalks, $6.67 \%$ of genotypes ranged from 30.1 to $40 \%$ bored stalks, $6.67 \%$ of genotypes ranged from 40.1 to $50 \%$ bored stalks, zero $\%$ of genotypes ranged from 50.1 to $60 \%, 60.1-70 \%, 70.1-80 \%, 80.1-90 \%$ and $90.1-$ $100 \%$ bored stalks. While, in the first ratoon season zero $\%$ of genotypes ranged from 0 to $10 \%$ bored stalks, $26.67 \%$ of genotypes ranged from 10.1 to $20 \%$ bored stalks, $40 \%$ of genotypes ranged from 20.1 to $30 \%$ bored stalks, $20 \%$ of genotypes ranged from 30.1 to $40 \%$ bored stalks, $13.33 \%$ of genotypes ranged from 40.1 to $50 \%$ bored stalks, zero $\%$ of genotypes ranged from 50.1 to $60 \%$, 60.1 to $70.0 \%, 70.1$ to $80 \%, 80.1$ to $90 \%$ and 90.1 to $100 \%$ bored stalks. While, in the second ratoon season $53.33 \%$ of genotypes ranged from 0 to $10 \%$ bored stalks, $6.67 \%$ of genotypes ranged from 10.1 to $20 \%$ bored stalks, $13.33 \%$ of genotypes ranged from 20.1 to $30 \%$ bored stalks, 13.33 of genotypes ranged from 30.1 to $40 \%$ bored stalks, $6.67 \%$ of genotypes ranged from 40.1 to $50 \%$ bored stalks, zero $\%$ of genotypes ranged from 50.1 to $60 \%$, 60.1 to $70.0 \%, 70.1$ to $80 \%$ bored stalks, $6.67 \%$ of genotypes ranged from 80.1 to $90 \%$ bored stalks and zero \% of genotypes ranged from 90.1 to $100 \%$ bored stalks. In general, the obtained results are in accordance with those reviewed by Salman et al. (2014); Fahmy et al. (2017) and Fahmy et al., (2019) who found that the relative susceptibility to C. agamemnon infestation measured as bored stalk percentage differed greatly among sugarcane varieties.

\subsubsection{Bored joints percentage (infestation intensity)}

Data illustrated in Table (4) and Figure (4) recorded that the used sugarcane genotypes significantly differ in their susceptibility to borer attack measured as bored joints $\%$ in both plant 
cane and $1^{\text {st }}$ ratoon. L 62-96 seemed to be the most susceptible genotype to borer attack recording the highest bored joints $\%$ in plant cane and $1^{\text {st }}$ ratoon seasons respectively (6.08 and 4.74\%). However, in the $2^{\text {nd }}$ ratoon the genotype G.T.54-9 recording
(9.03\%) compared other tested genotypes similar results were reviewed by Ali et al. (2001).

All sugarcane genotypes showed severe symptoms of infestation by $C$. agamemnon in the plant cane, the first ratoon and second ratoon seasons.

Table 4. Susceptibility of sugarcane genotypes to infestation with C. agamemnon (Bored joints \%) during three successive seasons

\begin{tabular}{|c|c|c|c|}
\hline \multirow[b]{2}{*}{ Genotypes } & \multicolumn{3}{|c|}{ Bored joints \% } \\
\hline & 2017/18 (PC) & 2018/19 (FR) & $2019 / 20(\mathrm{SR})$ \\
\hline G.2003-47 & $1.20^{\mathrm{efg}}$ & $1.89^{\mathrm{Fg}}$ & $3.55^{\mathrm{d}}$ \\
\hline ЕH 88/5-27 & $1.99 \mathrm{de}$ & $1.28^{\mathrm{g}}$ & 2.31 ef \\
\hline F. 150 & $0.61^{\mathrm{g}}$ & $2.88^{\mathrm{cd}}$ & $0.45^{\mathrm{g}}$ \\
\hline M 57-35 & $0.69^{g}$ & $2.50^{\mathrm{cdef}}$ & 2.5 ef \\
\hline F 161 & $1.06^{\mathrm{fg}}$ & 2.23 ef & $0.49^{g}$ \\
\hline SP72-5181 & $0.90^{\mathrm{g}}$ & $2.32^{\text {cdef }}$ & $7.22^{b}$ \\
\hline G. $2008-64$ & $3.66^{b}$ & $2.93^{c}$ & $0.42^{\mathrm{g}}$ \\
\hline G. $2003-49$ & $1.08^{\mathrm{fg}}$ & $4.21^{\mathrm{ab}}$ & $2.82 \mathrm{de}$ \\
\hline L 62-96 & $6.08^{a}$ & $4.74^{\mathrm{a}}$ & $5.00^{\mathrm{c}}$ \\
\hline G. $2008-20$ & $0.86^{\mathrm{g}}$ & $3.99^{b}$ & $0.70^{g}$ \\
\hline G. $2007-61$ & $0.95^{\mathrm{g}}$ & 2.49 cdef & $0.66^{\mathrm{g}}$ \\
\hline SP $81-3250$ & $1.87 \mathrm{def}$ & $2.76^{\text {cde }}$ & $0.24^{\mathrm{g}}$ \\
\hline CO 182 & $2.62^{\mathrm{cd}}$ & $2.67^{\text {cde }}$ & 3.13 de \\
\hline G.2006-36 & $1.20^{\mathrm{efg}}$ & $2.28 \mathrm{def}$ & $1.74^{\mathrm{f}}$ \\
\hline G.T.54-9 & $2.89 \mathrm{bc}$ & 2.53 cde & $9.03^{\mathrm{a}}$ \\
\hline
\end{tabular}




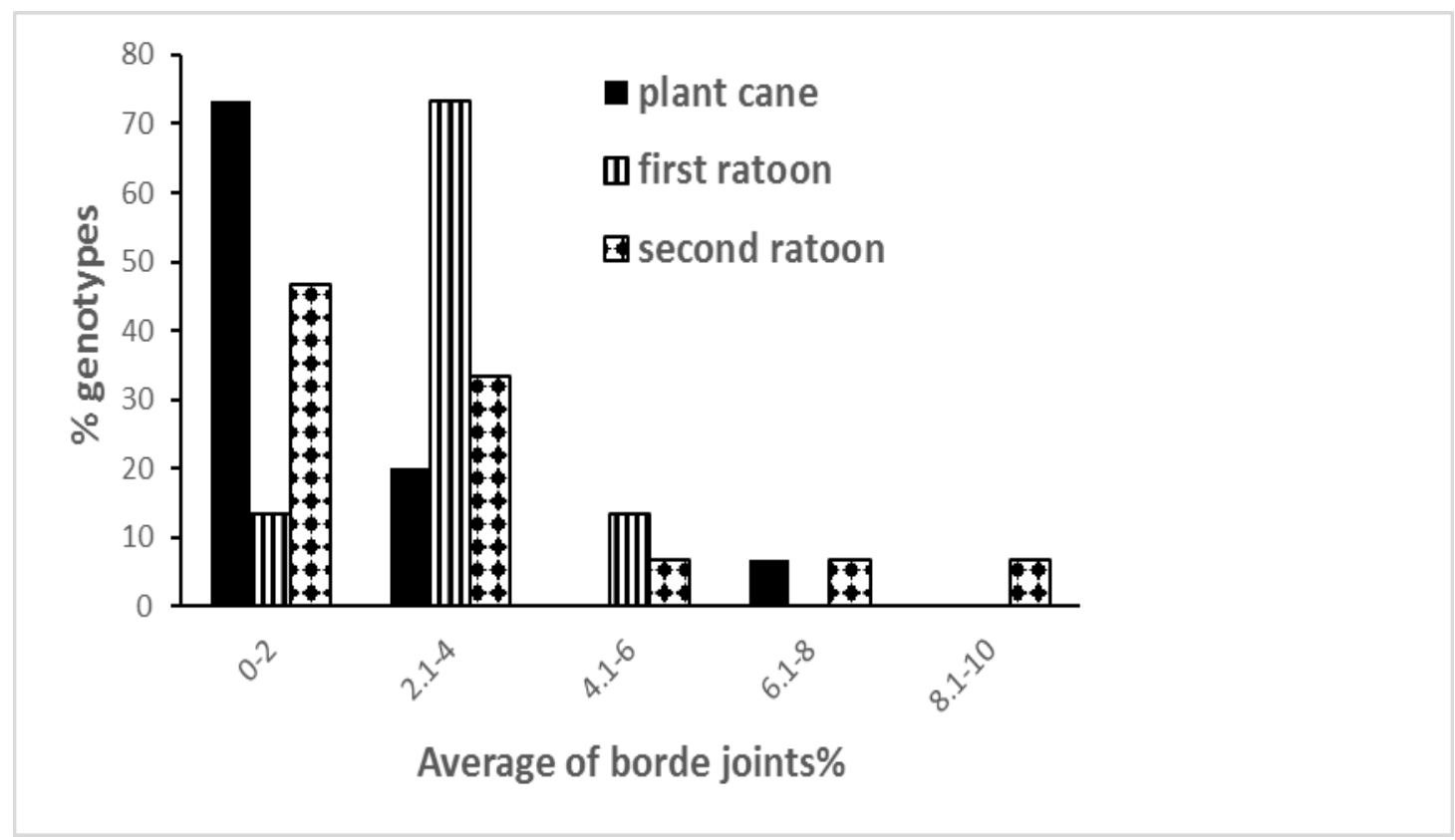

Figure 4. Percentage of sugarcane genotypes to infestation with C. agamemnon (Bored joints \%) during three successive seasons.

In plant cane season, $73.33 \%$ of genotypes ranged from 0.0 to $2 \%$ bored joints, $20 \%$ of genotypes ranged from 2.1 to $4 \%$ bored joints, zero $\%$ of genotypes ranged from 4.1 to $6 \%$ bored joints, $6.67 \%$ of genotypes ranged from 6.1 to $8 \%$ bored joints and zero $\%$ of genotypes ranged from 8.0 to $10 \%$ bored joints.

While, in the $1^{\text {st }}$ ratoon season $13.33 \%$ of genotypes ranged from 0.0 to $2 \%$ bored joints, $73.33 \%$ of genotypes ranged from 2.1 to $4 \%$ bored joints, $13.33 \%$ of genotypes ranged from 4.1 to $6 \%$ bored joints, zero $\%$ of genotypes ranged from 6.1 to $8 \%$ and 8.1 to $10 \%$ bored joints. While, in the $2^{\text {nd }}$ ratoon season $46.67 \%$ of genotypes ranged from 0.0 to $2 \%$ bored joints, $33.33 \%$ of genotypes ranged from 2.1 to $4 \%$ bored joints, $6.67 \%$ of genotypes ranged from 4.1 to $6 \%$ bored joints, 6.67 $\%$ of genotypes ranged from 6.1 to $8 \%$ and $6.67 \%$ of genotypes ranged from 8.1 to $10 \%$ bored joints.

\subsubsection{Girdled stalks percentage}

Data presented in Table (5) and Figure (5) suggested that, girdled stalks\% in both plant cane, $1^{\text {st }}$ ratoon and $2^{\text {nd }}$ ratoon seasons significantly differed among sugarcane genotypes. In plant cane and $1^{\text {st }}$ ratoon seasons the genotype L62-96 exhibited the highest girdled stalks\% recording (20\%). On the contrary, in the $2^{\text {nd }}$ ratoon season the genotype G.T.54-9 was recorded the highest girdled stalks\% (26.67\%) compared other tested genotypes. On the other hand, EH 88/5-27, F 161, G. 2003-49, G. 2008-20, G. 2007-61, CO 182 and G.2006-36 were the most tolerant genotypes in plant cane recording the lowest girdled stalks percentage $(0.0 \%)$, respectively. But, in the $1^{\text {st }}$ ratoon one genotype G.2003-47 recording the lowest girdled stalks\% (0.0\%). Whereas, in the second ratoon season two genotypes (F. 161 and G. 2008-64) were recorded the lowest girdled stalks\% $(0.0 \%)$. In the plant cane, first ratoon and second ratoon seasons, approximately 46.67 (seven genotypes), $6.67 \%$ (one genotype) and $13.33 \%$ (two genotypes) of genotypes had zero girdled stalks\%, respectively. All sugarcane genotypes showed severe symptoms of infestation by $C$. agamemnon (girdled stalks\%) except EH88/5-27, F 161, G. 2003-49 , G. 2008-20, G. 2007-61, CO 182 and G.2006-36 in plant cane and G.2003-47 in the first ratoon \& F 161 and G. 2008-64 in the second 
ratoon seasons. The results are in agreement with those of Salman et al. (2014) showed that G.200347 was the most susceptible variety in which the percentage of infestation was $21.67 \%$. On the contrary G.98-28 was the least susceptible one $(6.36 \%)$. Remaining varieties were moderate susceptibility to infestation by C. agamemnon.

Table 5. Susceptibility of sugarcane genotypes to infestation with C. agamemnon (Girdled stalks\%) during three successive seasons.

\begin{tabular}{|c|c|c|c|}
\hline \multirow[b]{2}{*}{ Genotypes } & \multicolumn{3}{|c|}{ Girdled stalks \% } \\
\hline & 2017/18 (PC) & 2018/19 (FR) & $2019 / 20$ (SR) \\
\hline G.2003-47 & $5.00^{b}$ & $0.00^{\mathrm{g}}$ & $10.00^{b c}$ \\
\hline EH 88/5-27 & $0.00^{\mathrm{c}}$ & $3.33 \mathrm{fg}$ & $6.67^{\mathrm{cd}}$ \\
\hline F. 150 & $5.00^{\mathrm{b}}$ & $15.00^{a b c d}$ & $6.67^{\mathrm{cd}}$ \\
\hline M 57-35 & $5.00^{\mathrm{b}}$ & 11.67 abcdef & $10.00^{b c}$ \\
\hline F 161 & $0.00^{\mathrm{c}}$ & 13.33 abcde & $0.00^{\mathrm{d}}$ \\
\hline SP72-5181 & $5.00^{\mathrm{b}}$ & $5.00 \mathrm{efg}$ & $16.67^{b}$ \\
\hline G. $2008-64$ & $5.00^{\mathrm{b}}$ & $16.67 \mathrm{abc}$ & $0.00^{\mathrm{d}}$ \\
\hline G. $2003-49$ & $0.00^{c}$ & $15.00^{\mathrm{abcd}}$ & $6.67^{\mathrm{cd}}$ \\
\hline L 62-96 & $20.00^{\mathrm{a}}$ & $20.00^{\mathrm{a}}$ & $16.67^{b}$ \\
\hline G. $2008-20$ & $0.00^{c}$ & $11.67^{\mathrm{abcdef}}$ & $6.67^{\mathrm{cd}}$ \\
\hline G. $2007-61$ & $0.00^{\mathrm{c}}$ & 10.00 bcdef & $6.67 \mathrm{~cd}$ \\
\hline SP $81-3250$ & $5.00^{\mathrm{b}}$ & $5.00 \mathrm{efg}$ & $6.67^{\mathrm{cd}}$ \\
\hline CO 182 & $0.00^{\mathrm{c}}$ & $8.33^{\text {cdefg }}$ & $6.67^{\mathrm{cd}}$ \\
\hline G.2006-36 & $0.00^{\mathrm{c}}$ & $6.67^{\operatorname{defg}}$ & $6.67^{\mathrm{cd}}$ \\
\hline G.T. 54-9 & $3.97^{\mathrm{b}}$ & $19.62^{a b}$ & $26.67^{\mathrm{a}}$ \\
\hline
\end{tabular}




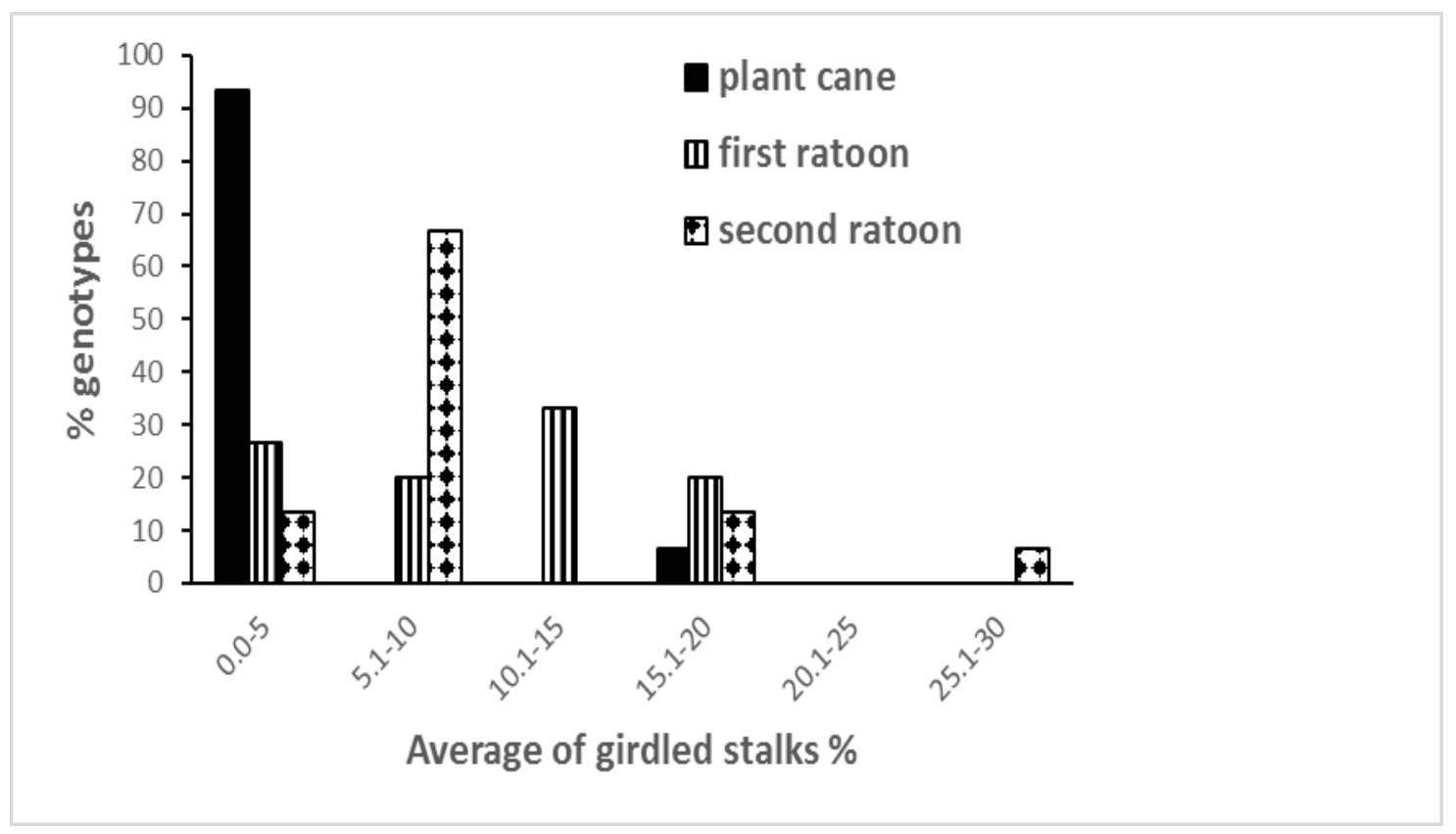

Figure 5. Percentage of sugarcane genotypes to infestation with C. agamemnon (girdled stalks \%) during three successive seasons.

In plant cane season, $93.33 \%$ of genotypes ranged from 0.0 to $5 \%$ girdled stalks, zero $\%$ of genotypes ranged from 5.1 to $10 \%$ \& 10.1 to $15 \%$ girdled stalks, $6.67 \%$ of genotypes ranged from 15.1 to $20 \%$ girdled stalks and zero\% of genotypes ranged from 20.1 to $25 \%$ \& $25.1-30$ girdled stalks. While, in the $1^{\text {st }}$ ratoon season $26.67 \%$ of genotypes ranged from 0.0 to $5 \%$ girdled stalks, $20 \%$ of genotypes ranged from 5.1 to $10 \%$ girdled stalks, $33.33 \%$ of genotypes ranged from 10.1 to $15 \%$ girdled stalks, $20 \%$ of genotypes ranged from 15.1 ton 20 girdled stalks and zero \% of genotypes ranged from 20.1 to $25 \%$ \& 25.1 to $30 \%$ girdled stalks. While, in the $2^{\text {nd }}$ ratoon season $13.33 \%$ of genotypes ranged from 0.0 to $5 \%$ girdled stalks, $66.67 \%$ of genotypes ranged from 5.1 to $10 \%$ girdled stalks, zero $\%$ of genotypes ranged from 10.1 to $15 \%$ girdled stalks, $13.33 \%$ of genotypes ranged from 15.1 to $20 \%$, zero \% of genotypes ranged from 20.1 to $25 \%$ girdled stalks and $6.67 \%$ of genotypes ranged from 25.1 to $30 \%$ girdled stalks.

\subsubsection{Mean no. holes/joint}

Data in Table (6) indicated that, mean no. holes/joint in plant cane, $1^{\text {st }}$ ratoon and $2^{\text {nd }}$ ratoon seasons significantly differed among sugarcane genotypes. In plant cane and $1^{\text {st }}$ ratoon the genotype L 62-96 exhibited the highest mean no. holes/joint recorded (0.065 and 0.080) respectively. On the contrary, in the $2^{\text {nd }}$ ratoon season the genotype SP72-5181 was recorded the highest mean no. holes/joint (0.184) compared other tested genotypes. On the other hand, F.150 was the most tolerant genotypes in plant cane recording the lowest mean no. holes/joint (0.006). While in the $1^{\text {st }}$ ratoon, one genotype EH 88/5-27 recording the lowest mean no. holes/joint (0.014). Whereas, in the $2^{\text {nd }}$ ratoon season three genotypes (F.150, F.161 and G.2007-61) were recorded the lowest mean no. holes/joint respectively. 
Table 6. Mean no. holes/ joint during three successive seasons (PC), (FR) and (SR) of the sugarcane genotypes due to with $C$. agamemnon infestation.

\begin{tabular}{|c|c|c|c|}
\hline \multirow[b]{2}{*}{ Genotypes } & \multicolumn{3}{|c|}{ Mean no. holes/joint } \\
\hline & 2017/18 (PC) & 2018/19 (FR) & 2019/20 (SR) \\
\hline G.2003-47 & $0.015^{\text {cde }}$ & $0.022^{\mathrm{cd}}$ & $0.053^{c}$ \\
\hline EH 88/5-27 & 0.023 bcde & $0.014^{\mathrm{d}}$ & $0.038^{\mathrm{cd}}$ \\
\hline F. 150 & $0.006^{\mathrm{e}}$ & $0.052^{a b}$ & $0.007^{\mathrm{e}}$ \\
\hline M 57-35 & $0.007^{\mathrm{e}}$ & $0.048^{b c}$ & $0.025 \mathrm{de}$ \\
\hline F 161 & $0.011^{\mathrm{de}}$ & 0.034 bcd & $0.007^{\mathrm{e}}$ \\
\hline SP72-5181 & $0.012^{\mathrm{de}}$ & $0.033^{\mathrm{bcd}}$ & $0.184^{\mathrm{a}}$ \\
\hline G. $2008-64$ & $0.037^{\mathrm{b}}$ & $0.036^{\mathrm{bcd}}$ & $0.008^{\mathrm{e}}$ \\
\hline G. $2003-49$ & $0.011^{\mathrm{de}}$ & $0.047^{b c}$ & $0.054^{\mathrm{c}}$ \\
\hline L 62-96 & $0.065^{\mathrm{a}}$ & $0.080^{\mathrm{a}}$ & $0.056^{\mathrm{c}}$ \\
\hline G. $2008-20$ & $0.009^{\mathrm{e}}$ & $0.047^{b c}$ & $0.021 \mathrm{de}$ \\
\hline G. $2007-61$ & $0.015^{\text {cde }}$ & $0.036^{\mathrm{bcd}}$ & $0.007^{\mathrm{e}}$ \\
\hline SP $81-3250$ & 0.019 bcde & $0.034^{\mathrm{bcd}}$ & $0.008^{\mathrm{e}}$ \\
\hline CO 182 & $0.030^{\mathrm{bcd}}$ & $0.034^{\mathrm{bcd}}$ & $0.034^{\text {cde }}$ \\
\hline G.2006-36 & $0.012^{\mathrm{de}}$ & 0.027 bcd & $0.030^{\text {cde }}$ \\
\hline G.T. 54-9 & $0.033 \mathrm{bc}$ & $0.042^{\mathrm{bcd}}$ & $0.116^{b}$ \\
\hline
\end{tabular}

\subsubsection{Mean no. holes/ bored joint}

Data illustrated in Table 7 recorded that, mean no. holes/ bored joint in plant cane, $1^{\text {st }}$ ratoon and $2^{\text {nd }}$ ratoon seasons significantly differed among sugarcane genotypes. In plant cane the genotype G. 2007-61 exhibited the highest mean no. holes/bored joint recorded (2.00). whereas, in the first ratoon season the genotype M 57-35 recorded the highest mean no. holes/ bored joint (1.95). On the contrary, in the $2^{\text {nd }}$ ratoon season the genotype G. 2008-20 recorded the highest mean no. holes/ bored joint (3.00) compared other tested genotypes. On the other hand, F. 150, M 57-35 and F 161 were the most tolerant genotypes in plant cane recording the lowest mean no. holes/ bored joint (1.00) respectively. While, in the $1^{\text {st }}$ ratoon one genotype (G. 2003-49) recorded the lowest mean no. holes/bored joint (1.12). Whereas, in the $2^{\text {nd }}$ ratoon season two genotypes (F161 and SP81-3250) were recorded the lowest mean no. holes/bored joint (0.67) respectively.

\subsubsection{Mean no. holes/ stalk}

Data arranged in Table 8 showed that, mean no. holes/ stalk in both plant cane, $1^{\text {st }}$ ratoon and $2^{\text {nd }}$ ratoon seasons significantly differed among sugarcane genotypes. In plant cane and $1^{\text {st }}$ ratoon seasons the genotype L 62-96 exhibited the highest 
mean no. holes/stalk recording (0.80 and 1.05) respectively. On the contrary, in the $2^{\text {nd }}$ ratoon season the genotype SP72-5181 recorded the highest mean no. holes/ stalk (2.30) compared other tested genotypes. On the other hand, three genotypes F. 150, M 57-35 and G. 200820 were the most tolerant genotypes in plant cane recording the lowest mean no. holes/ bored joint $(0.10)$. While, in the $1^{\text {st }}$ ratoon one genotype (EH 88/5-27) recorded the lowest mean no. holes/stalk (0.18). Whereas, in the $2^{\text {nd }}$ ratoon season one genotype (SP 81-3250) was recorded the lowest mean no. holes/stalk (0.07).

Table 7. Mean no. holes/ bored joint during three successive seasons (PC), (FR) and (SR) of the sugarcane genotypes due to with C. agamemnon infestation

\begin{tabular}{cccc}
\hline Genotypes & \multicolumn{3}{c}{ Mean no. holes/ bored joint } \\
\cline { 2 - 4 } & $2017 / 18(\mathrm{PC})$ & $2018 / 19^{(\mathrm{FR})}$ & $2019 / 20(\mathrm{SR})$ \\
\hline G.2003-47 & $1.25^{\mathrm{bc}}$ & $1.21^{\mathrm{ef}}$ & $1.57^{\mathrm{de}}$ \\
EH 88/5-27 & $1.21^{\mathrm{bc}}$ & $1.25^{\mathrm{ef}}$ & $1.67^{\mathrm{cd}}$ \\
F. 150 & $1.00^{\mathrm{c}}$ & $1.85^{\mathrm{ab}}$ & $1.67^{\mathrm{cd}}$ \\
M 57-35 & $1.00^{\mathrm{c}}$ & $1.95^{\mathrm{a}}$ & $1.00^{\mathrm{h}}$ \\
F 161 & $1.00^{\mathrm{c}}$ & $1.56^{\mathrm{bcd}}$ & $0.67^{\mathrm{i}}$ \\
SP72-5181 & $1.50^{\mathrm{b}}$ & $1.45^{\mathrm{cde}}$ & $2.57^{\mathrm{b}}$ \\
G. 2008-64 & $1.04^{\mathrm{c}}$ & $1.23^{\mathrm{ef}}$ & $1.33^{\mathrm{ef}}$ \\
G. 2003-49 & $1.00^{\mathrm{c}}$ & $1.12^{\mathrm{f}}$ & $1.92^{\mathrm{c}}$ \\
L 62-96 & $1.07^{\mathrm{c}}$ & $1.68^{\mathrm{abc}}$ & $1.12^{\mathrm{fgh}}$ \\
G. 2008-20 & $1.00^{\mathrm{c}}$ & $1.18^{\mathrm{ef}}$ & $3.00^{\mathrm{a}}$ \\
G. 2007-61 & $2.00^{\mathrm{a}}$ & $1.49^{\mathrm{cde}}$ & $1.00^{\mathrm{h}}$ \\
SP 81-3250 & $1.00^{\mathrm{C}}$ & $1.28^{\mathrm{def}}$ & $0.67^{\mathrm{i}}$ \\
CO 182 & $1.15^{\mathrm{bc}}$ & $1.29^{\mathrm{def}}$ & $1.07^{\mathrm{gh}}$ \\
G.2006-36 & $1.00^{\mathrm{c}}$ & $1.42^{\mathrm{cdef}}$ & $1.56^{\mathrm{de}}$ \\
G.T. 54-9 & $1.30^{\mathrm{bc}}$ & $1.66^{\mathrm{abc}}$ & $1.28^{\mathrm{fg}}$ \\
\hline
\end{tabular}

\subsection{Principle Component Biplot Analysis (PCA)}

PCA presented in (Fig 6) was performed for 11 traits of sugarcane, PCA study the interrelation among the characteristics and genotypes, the data of PC1 and PC2 axes estimated for $90.31 \%$ of the total variability. It found high positive correlation between bored stalks\%, bored joints \%, girdled stalks \%, mean no. holes/joint, mean no. holes/bored joint, mean no. holes/ stalk with brix $\%$ in the positive direction and brix $\%$ in the positive direction. Juice quality traits (recovery, purity and sucrose) were negatively correlated with mean no. holes/joint, mean no. holes/bored joint, 
Table 8. Mean no. holes/ stalk during three successive seasons (PC), (FR) and (SR) of the sugarcane genotypes due to with $C$. agamemnon infestation

\begin{tabular}{|c|c|c|c|}
\hline \multirow{2}{*}{ Genotypes } & \multicolumn{3}{|c|}{ Mean no. holes/ stalk } \\
\hline & 2017/18 (PC) & 2018/19 (FR) & 2019/20 (SR) \\
\hline G.2003-47 & $0.25^{\mathrm{cd}}$ & $0.33^{\text {ef }}$ & $0.60^{\text {cde }}$ \\
\hline EH 88/5-27 & 0.35 bcd & $0.18^{\mathrm{f}}$ & $0.50^{\mathrm{de}}$ \\
\hline F. 150 & $0.10^{\mathrm{d}}$ & $0.95^{\mathrm{ab}}$ & $0.10^{\mathrm{h}}$ \\
\hline M 57-35 & $0.10^{\mathrm{d}}$ & $0.68^{\mathrm{bcd}}$ & $0.30^{\mathrm{fg}}$ \\
\hline F 161 & $0.20^{\mathrm{cd}}$ & $0.48^{\text {cde }}$ & $0.10^{\mathrm{h}}$ \\
\hline SP72-5181 & $0.20^{\mathrm{cd}}$ & $0.53^{\text {cde }}$ & $2.30^{\mathrm{a}}$ \\
\hline G. 2008-64 & $0.60^{\mathrm{ab}}$ & $0.55^{\text {cde }}$ & $0.13^{\text {gh }}$ \\
\hline G. $2003-49$ & $0.20^{\mathrm{cd}}$ & 0.70 bcd & $0.77^{\mathrm{c}}$ \\
\hline L 62-96 & $0.80^{\mathrm{a}}$ & $1.05^{\mathrm{a}}$ & $0.67^{\mathrm{cd}}$ \\
\hline G. $2008-20$ & $0.10^{d}$ & $0.68^{\mathrm{bcd}}$ & $0.30^{\mathrm{fg}}$ \\
\hline G. $2007-61$ & $0.25^{\mathrm{cd}}$ & 0.58 cde & $0.10^{\mathrm{h}}$ \\
\hline SP 81-3250 & $0.25^{\mathrm{cd}}$ & $0.50^{\text {cde }}$ & $0.07^{\mathrm{h}}$ \\
\hline CO 182 & $0.45 \mathrm{bc}$ & $0.48 \mathrm{de}$ & $0.50 \mathrm{de}$ \\
\hline G.2006-36 & $0.20^{\mathrm{cd}}$ & 0.38 ef & $0.47^{\text {ef }}$ \\
\hline G.T. 54-9 & $0.42^{b c}$ & $0.78^{a b c}$ & $1.67^{\mathrm{b}}$ \\
\hline
\end{tabular}

mean no. holes/ stalk (Mehareb and Mansoup 2020), that reported high positive correlation between bored stalks $\%$ and bored joints and brix $\%$ in the positive direction.

Bored joints $\%$ and girdled stalks $\%$ were negatively correlated with cane and sugar yield. These results with were harmony with (Mehareb and Mansoup 2020), it found bored stalks and bored joints\% were negatively correlated with cane and sugar yield. Sugar yield was significantly and positively correlated with juice purity $\%$, followed by sugar recovery $\%$, then sucrose $\%$ and brix $\%$. Which is in agreement with Gadallah and Mehareb (2020), who found that positively correlated between sugar yield with purity\%, sugar recovery $\%$, sucrose $\%$ and brix $\%$. 


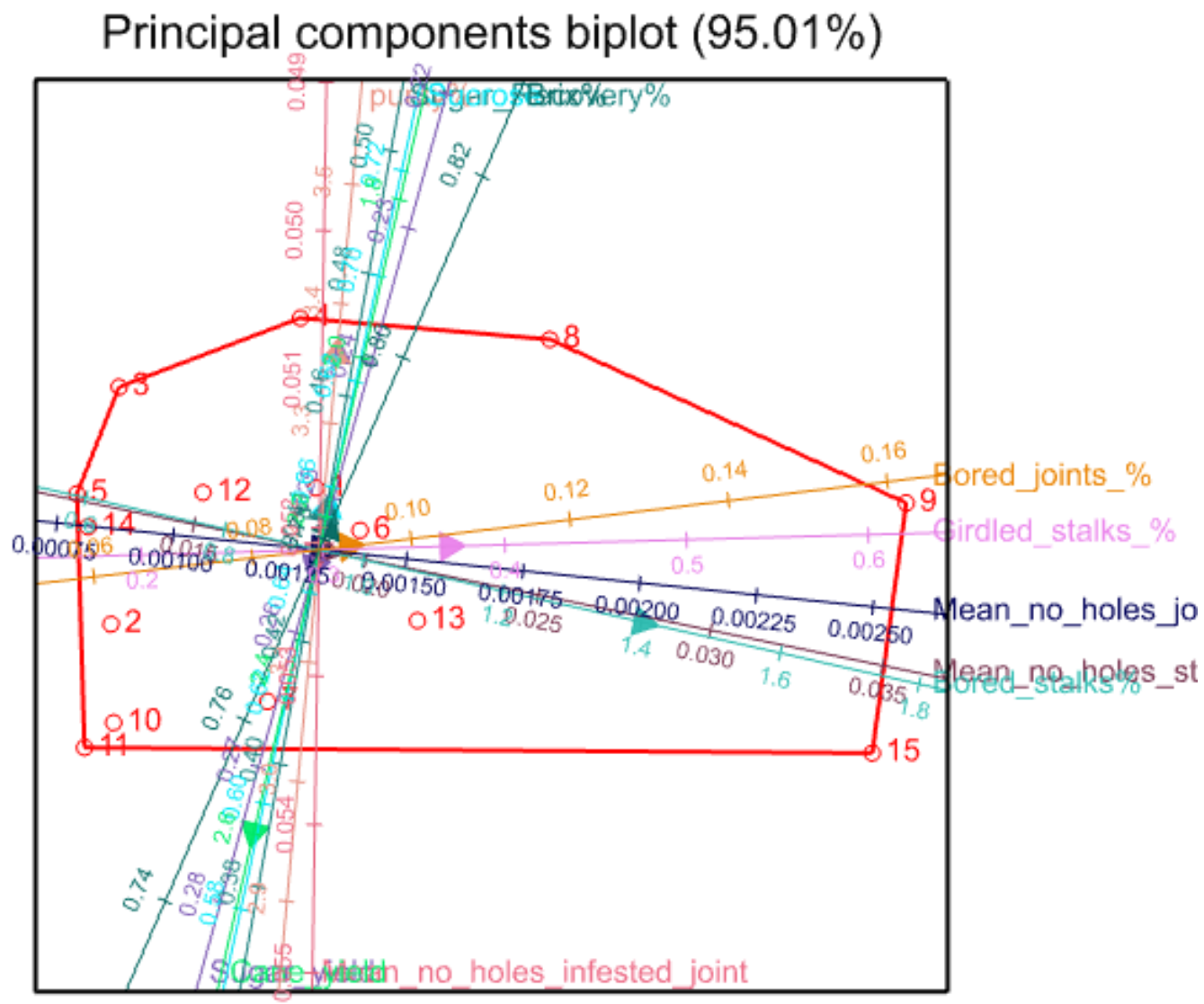

\section{PC-1 $(74.5 \%)$}

Figure 6: Biplot based on principal component analysis for agronomical, technological, and insect characters in 15 sugarcane genotypes (O1-O18).

\section{References}

A.O.A.C. (1995) 'Official methods of analysis. association of official analytical chemists', Washington, D.C., USA, pp. 642.

Abo Elenen, Fouz F.M., Mehareb, E.M., Ghonema, M.A., and El-Bakry, A. (2018) 'Selection in sugarcane germplasm under the Egyptian conditions', J. Agric., 3 (3), pp. 113.
Ali, M.K., Allam, S.M., Abaziad, A.A., and Maria Beshay G. (2001). 'Effect of stalk borer intensity Chilo agamemnon (PLB) on juice quality of three sugar borer varieties', Egypt, J. Appl. Sci., 16 (1), pp. 99-104.

Bashir, S., Hassan, M., Khan, N.F.Z. and Ali, Z. (2013).' Ratooning potential of different promising sugarcane genotypes at varying harvesting dates', ARPN 
Journal of Agricultural and Biological Science, 8 (5), 437-440.

Fahmy, A.M., Desoky, A.S.S. and Galal, M.O.A. (2019). 'evaluation of some promising sugarcane varieties for infestation with two sugarcane borers, yield and quality under different row spacing in Luxor governorate, Egypt', International Journal of Research Studies in Zoology, 5 (3), pp. 11-21.

Fahmy, A.M., Osman, M.A.M. and Galal, M.O.A. (2017) 'Yield, quality and natural infestation with insect and disease of four sugarcane varieties as affected by different levels of potassium fertilization', J. Plant Prot. and Path., Mansoura Univ., 8 (12), pp. 687-693.

Gadallah, A.F.I., and Mehareb, E.M. (2020) 'Yield and quality of some sugarcane varieties as affected by irrigation number', SVUInternational Journal of Agricultural Science. 2 (2), pp. 144-165.

Gomez, K.A. and Gomez, A.A. (1984). 'Statistical procedures for agricultural research', John Wiley, New York, pp. 680.

Gravois, K.A., Zhou, M.M., Hoffmann, Piperidis G. and Badaloo, G. (2016). 'Breeding new sugarcane varieties with enhanced ratooning ability' Proceedings of the International Society of Sugar Cane Technologists, 29,1683-1690.

Harman, H.H. (1976) 'Modern Factor Analysis', 3rd Edition, The University of Chicago Press, Chicago.

Khan, I.A., Seema, N., Raza, S., Yasmine, S. and Bibi, S. (2013). 'Environmental interactions of sugarcane genotypes and yield stability analysis of sugarcane, Pak. J. Bot., 45(5), pp. 1617-1622.
Kumar, A., Paul, S., and Chand, H. (2019). 'Insect pests of sugarcane and their management: an overview' In book: Advances in Agricultural Entomology, New Delhi, India, 3, pp. 1-18.

Mahmoud, E.A., El-Hinnawy, H.H. Masri, M.I., Mohamed, B.D. and Mehareb, E.M. (2012). 'Performance and repeatability for some agronomic traits in sugarcane crosses at early selection stages', Egyptian journal of plant breeding. 16 (2), pp. 237-255.

Masri, M.I. and Amein, M.M.M. (2015). 'Yield potential and ratooning ability of some sugarcane genotypes', J. Plant Breed. Crop Sci., 7 (8), 262-274.

Mehareb, E. M., Osman, M.A.M. and Fahmy, A.M. (2018). 'Screening sugarcane genotypes for the lesser sugarcane borer, Chilo agamemnon Bels. and four main diseases resistance in Egypt', Egypt. J. Plant Breed., 22 (4), pp. 659683.

Mehareb, E.M and Galal, M.O.A. (2017). 'Ratooning ability for some promising Egyptian sugarcane varieties', Indian Journal of Sugarcane Technology, 32 (02), pp. 50-59.

Mehareb, E.M. and Abazied, S.R. (2017). 'Genetic variability of some promising sugarcane varieties (Saccharum spp) under harvesting ages for juice quality traits, cane and sugar yield', J. Agric. Res., 2 (2), pp. 1-14.

Mehareb, E.M. and El-Mansoub, M.M.A. (2020). 'Genetic parameters and principal components biplot for agronomical, insect and Pathological traits in some sugarcane genotypes', SVUInternational Journal of Agricultural Science. 2 (2), pp, 77-93. 
Mehareb, E.M., kun,Y., Jun, Z., Aboelenen, F.F., Wei, Q., Fenggang, Z., Jiayong, L., Hongming, X., Li, Y., Peifang, Z. Yong, Z. and Caiwen, W. (2017). 'Evaluation of seventy six sugarcane families at early selection stages', Journal of Plant Breeding and Crop Sci. 9 (9), pp. 151-159.

Mendes, A.C., Botelho, P.S., and Macedo, N. (1980). 'Correlation between the intensity of infestation and population index of the sugarcane borer Diatraea sacchralis (Fabr.) ', Proc. ISSCT, 17, Bull. 8)

Ramdoyal, K.R., Domaingue, F.H.F., Fong, S.P. and Julien, M.H.R. (1986). Interrelationships between different crops of a cane cycle and impact on selection strategies in sugarcane. Proc. Int. Soc. Sugar Cane Technol., 19, pp. 447-453.

Salman, A.M.A., Abazied, A.A. and Fahmy, A.M. (2014). 'Effect of some cultural practices on the infestation level of Chilo agamemnon Bles., infesting sugarcane varieties at Luxor Governorate', Middle East j. Agric. Res. 3 (3), pp. 569-575.

Saxena, P., Srivastava, R.P. and Sharma, M.L. (2010). 'Impact of cut to crush delay and bio-chemical changes in sugarcane', Australian Journal of Crop Science, 4(9), 692-699.

Sharma, S., Sandhu, S.K. and Singh, H.S. (2011). 'Field evaluation of sugarcane germplasm against major pests', Indian Journal of Sugarcane Research and Development, 6, pp. 81-86.

Singh, R.K. and Singh, G.P. (1998) 'Effect of sampling time on efficacy of selection for quality traits in sugarcane', Sugar Cane (3), pp. 13-17.

Tomaz, A.C., Gonçalves, M.T.V., Resende, M.D.V., Brasileiro, B..P., Peternelli, L.A. and Barbosa, M.H.P. (2020). 'Genetic parameters and selection of sugarcane for borer resistance in the advanced selection stage', Crop Breeding and Applied Biotechnology, 2 (1), pp. 1-11.

Tomaz, A.C., Wartha, C.A., Resende, M.D.V., Brasileiro, B..P., Peternelli, L.A. and Barbosa, M.H.P. (2019). 'Genetic parameters and selection of sugarcane in early selection stages for resistance to sugarcane borer Diatraea saccharalis', Crop Breeding and Applied Biotechnology 19, pp. 208-216.

Yadav, R.L. and Sharma, R.K. (1980) 'Effect of nitrogen level and harvesting date on quality characteristics and yield of four sugarcane genotypes', Indian J. Agric. Sci. (50), pp. 581-589.

Zhao, L., Yang, K., Zhao, P., Qin, W., Zhao, Y., Zhu, J., Zan, F., Zhao, J., Lu, X., Wu, C., Burner, D.M., Chen, X. and Liu, J. (2020). ' Sugarcane root distribution and growth as affected by genotype and crop cycle, Bragantia, 79 (2), pp. 1-4.

Zhou, M.M. and Shoko, M.D. (2012). 'Simultaneous selection for yield and ratooning ability in sugarcane genotypes using analysis of covariance', South African Journal of Plant and Soil, 29 (2), pp. 93-100. 